\title{
Erratum to: Solvent-free geranyl oleate production by enzymatic esterification
}

\author{
Natália Paroul · Luana Paula Grzegozeski • Viviane Chiaradia • \\ Helen Treichel · Rogério L. Cansian · J. Vladimir Oliveira • \\ Débora de Oliveira
}

Published online: 30 December 2010

(C) Springer-Verlag 2010

\begin{abstract}
This study reports the maximization of geranyl oleate production by esterification of geraniol and oleic acid in a solvent-free system using a commercial lipase as catalyst. The operating conditions that maximized geranyl oleate production were determined to be $40{ }^{\circ} \mathrm{C}$, geraniol to oleic acid molar ratio of 5:1, $150 \mathrm{rpm}$ and $10 \mathrm{wt} \%$ of enzyme, with a resulting reaction conversion of about $93 \%$. After determining the best reaction parameters, a kinetic study was performed and the results obtained in this step allow to conclude that an excess of alcohol (alcohol to acid molar ratio of 5:1), relatively low enzyme concentration (5 wt $\%$ ) and temperature of $50{ }^{\circ} \mathrm{C}$ afforded nearly complete reaction conversion after $1 \mathrm{~h}$ of reaction. New experimental data on enzymatic esterification of geraniol and oleic acid for geranyl oleate production are reported in this work, showing a promising perspective of the technique to overcome the inconvenience of the chemicalcatalyzed route.
\end{abstract}

Owing to an unfortunate oversight, the wrong version of this article was submitted. The correct version is given here.

The online version of the original article can be found under doi:10.1007/s00449-010-0475-x.

N. Paroul · D. de Oliveira

Programa de Pós-Graduação em Biotecnologia,

Universidade de Caxias do Sul, Caxias do Sul, RS, Brazil

N. Paroul · L. P. Grzegozeski · V. Chiaradia ·

H. Treichel $(\bowtie) \cdot$ R. L. Cansian · J. V. Oliveira · D. de Oliveira Universidade Regional Integrada do Alto Uruguai e das Missões, URI-Campus de Erechim, Av. Sete de Setembro, 1621, Erechim, RS 99700-000, Brazil

e-mail: helen@uricer.edu.br
Keywords Geraniol · Geranyl oleate · Novozym 435 . Solvent-free system

\section{Introduction}

Production of flavors and fragrances through natural substances as starting raw materials has been under intense development since the last three decades. Biotechnology as an emerging science at the end of the last century allowed the development of new aromas, making basis and constituting the backbone what would be named lately as bioindustries. Despite the huge and fast development of the biotechnology field, several years later the chemical synthesis has still been largely employed to produce such kind of compounds [1]. To take a glance at the flavor and fragrance in worldwide market, until recently, the synthetic compounds found wide application in food, drink and pharmaceutical industries, moving around US\$ 16 billions in 2003 [2].

In spite of the fact that most of these compounds are obtained by chemical synthesis or by extraction from plants, application of new biotechnological processes has enhanced over the last decades [3, 4]. In this sense, biocatalysis may represent a potential alternative to chemical synthesis, especially in cases where the production of compounds with high stereo- or regioselectivities purity is involved. Furthermore, the growing preference for natural products by the consumers has impelled the flavor and fragrance market based on the biotechnological route.

The use of hydrolytic enzymes as esterases, proteases and peptidases in organic synthesis has become a common practice in the last years, both in scientific and industrial environment. In a general way, the main advantages of 
using these biocatalysts rely on the high activities exhibited in water and organic solvents and the ability to convert a broad number of substrates with high stereospecificity [5].

Examples concerning the application of primary alcohols as substrates for synthesis reactions catalyzed by lipases can be found in the literature [6, 7]. However, a full inspection of available literature permitted us to observe a lack of information regarding the production of geranyl oleate, an important flavor compound, with widespread application in the cosmetic, pharmaceutical and food industries, through enzymatic esterification of geraniol and oleic acid. Geraniol is a major constituent of several essential oils, such as roses and citronella and is also present in lower concentrations in geranium, lemon and several other essences.

Based on these aspects, the main objective of this work is to investigate the enzymatic production of geranyl oleate using geraniol and oleic acid as substrates in solvent-free system. A kinetic study was also performed toward assessing the influence of substrates molar ratio, enzyme concentration and temperature on reaction conversion. At the maximized experimental condition, the cycles of use of the immobilized enzyme were also determined.

\section{Materials and methods}

\section{Substrates and enzyme}

Geraniol (Vetec, 97\% purity) and oleic acid (Quimex, 97\% purity) were used as substrates for the esterification reactions. Molecular sieves of $4 \AA$ were purchased from Sigma-Aldrich. The commercial lipase used in this work was Candida antarctica (Novozym 435) immobilized on a macroporous anionic resin, purchased from Novozymes Brazil (Araucária, PR, Brazil).

\section{Determination of esterification activity}

The enzyme activity was determined as the initial rates in esterification reactions between lauric acid and propanol at a molar ratio of $3: 1$, temperature of $60^{\circ} \mathrm{C}$ and enzyme concentration of $5 \mathrm{wt} \%$ in relation to the substrates. At the beginning of the reaction, samples containing the mixture of lauric acid and propanol were collected, and the lauric acid content was determined by titration with $\mathrm{NaOH}$ $0.04 \mathrm{~N}$. After the addition of the enzyme to the substrates, the mixture was kept at $60{ }^{\circ} \mathrm{C}$ for $15 \mathrm{~min}$. Then, the lauric acid consumption was determined. One lipase activity unit $\left(U_{\mathrm{E}}\right)$ was defined as the amount of enzyme necessary to consume $1 \mu \mathrm{mol}$ lauric acid/min at the established experimental conditions presented previously [8]. All enzymatic activity determinations were replicated at least three times.
Evaluation of the solubility of oleic acid in geraniol

As a preliminary step, the solubility of the substrates was evaluated at room temperature $\left(25^{\circ} \mathrm{C}\right)$ and different geraniol to oleic acid molar ratio $(1: 1,2: 1,3: 1,6: 1$ and 9:1) by visual inspection of the mixtures for each tested conditions. This procedure was adopted to verify the need of using organic solvents to promote the efficient contact between the substrates and catalyst. Nevertheless, it was experimentally observed by visual observation that geraniol presented complete miscibility in oleic acid, independent of the molar ratios tested, with the formation of homogeneous, translucent solutions, hence not being necessary the use of organic solvents. All steps of the work were then carried out in solvent-free system.

\section{Experimental procedure for enzymatic esterification}

The esterification reactions were performed by preparing a reactional mixture of geraniol, oleic acid (at pre-established molar ratios) and molecular sieves $(20 \mathrm{mg} / \mathrm{mL}$ of substrates) in a $50 \mathrm{~mL}$ Erlenmeyer. After complete dissolution of the substrates, the enzyme, previously activated in oven at $40{ }^{\circ} \mathrm{C}$ and $60 \mathrm{~min}$, was added to the mixture. All experiments were carried out in an orbital shaker at constant agitation of $150 \mathrm{rpm}$. After the reaction time completion, the biocatalyst was filtered for later measurement of enzyme activity and samples were kept at $5{ }^{\circ} \mathrm{C}$ for further analysis and determination of reaction conversion.

\section{Determination of reaction conversion}

Quantitative analyses of geranyl esters produced were conducted in a gas chromatography (Shimadzu GC-2010) equipped with data processor, using a capillary column of fused silica INOWAX $(30 \mathrm{~m}$ length $\times 250 \mu \mathrm{m}$ i.d. $\times$ $0.25 \mu \mathrm{m}$ thickness), flame ionization detector, with the following temperature program: $40-180{ }^{\circ} \mathrm{C}\left(3^{\circ} \mathrm{C} / \mathrm{min}\right)$, $180-230{ }^{\circ} \mathrm{C}\left(20{ }^{\circ} \mathrm{C} / \mathrm{min}\right), 230{ }^{\circ} \mathrm{C}(20 \mathrm{~min})$, injector temperature $250{ }^{\circ} \mathrm{C}$, detector at $275^{\circ} \mathrm{C}$, injection in the mode split, ratio of split $1: 100, \mathrm{H}_{2}(56 \mathrm{kPa})$ as carrier gas, injected volume of $0.4 \mu \mathrm{L}$ of sample diluted in $n$-hexane (1:10). Reaction conversion was calculated based on the reduction of area of limiting reagent on the basis of reaction stoichiometry [9].

Evaluation of geranyl oleate production

The sequential experimental design technique was used for the determination of conditions that maximize the reaction conversion. A $2^{3}$ full experimental design with triplicate of central point was employed in this step to maximize the process conversion. Based on preliminary experiments 
(data not shown) and previous work performed by our research group [9], reaction time was fixed at $6 \mathrm{~h}$ and experiments were carried out as described before. The variables studied were temperature $\left(40-60{ }^{\circ} \mathrm{C}\right)$, geraniol/ acid molar ratio $(1: 1$ to $5: 1)$ and enzyme concentration (1-10 wt \%, based on the substrates amount).

After analyzing the results of the first experimental design, a second $2^{2}$ central composite rotatable design (CCRD) was carried out for the maximization of geranyl oleate production, varying the substrates molar ratio (1:1 to $5: 1)$ and enzyme concentration (1-10 wt\%).

The software Statistica ${ }^{\circledR} 6.0$ (Statsoft Inc) was used to assist the design and the statistical analysis of experimental information, adopting in all cases studied a confidence level of $95 \%(p<0.05)$.

Kinetic evaluation of enzymatic production of geranyl oleate

After maximizing the experimental conditions, kinetic experiments were performed with substrates molar ratio of $1: 1,3: 1$ and 5:1, enzyme concentration of 1, 2, 5.5 and $10 \mathrm{wt} \%$ (by weight of substrates) and temperature ranging from $40-60{ }^{\circ} \mathrm{C}$. It may be important to emphasize that in all cases, destructive experiments, without sampling, were carried out at times of $0.5,1,1.5,2,3,4,5$ and $6 \mathrm{~h}$.

After each experimental run, the enzyme was separated from the reactional medium and washed twice with $10 \mathrm{~mL}$ of $n$-hexane, following the methodology described by Castro et al. [10]. The recuperated enzyme was kept in desiccator for $24 \mathrm{~h}$ and, after this period, the enzyme activity was determined.

\section{Results and discussion}

Evaluation of geranyl oleate production

To assess the effects of alcohol to acid molar ratio, enzyme concentration and temperature on geranyl propionate production, a factorial $2^{3}$ experimental design with central point triplicate was adopted. The matrix of the first experimental design with coded and real values of variables and the response in terms of geranyl oleate production are presented in Table 1. From this table, one can see that distinct conversions were obtained as a function of the various levels studied. Higher conversions were obtained at substrates molar ratio of 1:1 and higher enzyme concentrations (runs 5 and 6, conversions of 90 and $85 \%$, respectively).

Results obtained in the first experimental design presented in Table 1 were statistically analyzed. As temperature presented a significant negative effect on geranyl oleate production and considering that mild working temperatures may represent energy savings, this variable was kept constant $\left(40{ }^{\circ} \mathrm{C}\right)$ in the second experimental design, which evaluated the effect of substrates molar ratio (MR) and enzyme concentration $(E)$ on product conversion. The interaction among all variables was also evaluated and it was noticed that negative significant effects $(p<0.05)$ were obtained. Results obtained in this step are presented in Table 2.

A preliminary analysis of this table permits us to verify that the experimental condition relative to the highest enzyme concentration and an excess of geraniol afforded the highest geranyl oleate production $(94.12 \%)$. Related to the alcohol to acid molar ratio, the literature $[11,12]$ points out that an excess of alcohol could positively affect the process conversion. In a general way, higher conversions were achieved at higher enzyme concentrations.

Results obtained in the second experimental design were statistically treated and permitted to validate an empirical coded model for geranyl oleate conversion in terms of substrates molar ratio and enzyme concentration, as presented in Eq. 1:

Conversion $(\%)=89.45+1.93 \mathrm{MR}+5.08 E-0.88 \mathrm{MR} E$

The correlation coefficient, $R(0.84)$, and the calculated $F$ higher than the tabled one (5.3) validated the empirical model $(p<0.1)$ for the production of geranyl oleate and permitted to build the response surface (a) and contour curve (b) presented in Fig. 1. The substrates molar ratio and enzyme concentration influenced significantly the product conversion. As observed in Fig. 1, higher conversions were obtained at higher molar ratios and enzyme concentrations.

Olsen et al. [13] evaluated the esterification of lavandulol to produce lavandulil acetate by enzymatic catalysis using Novozym 435, acetic acid as acyl donator and supercritical $\mathrm{CO}_{2}$ as solvent. The process was optimized verifying the effect of temperature, pressure and density of the solvent. Conversions of about $86 \%$ were observed for substrates concentration of $60 \mathrm{mM}$, temperature of $60{ }^{\circ} \mathrm{C}$ and $10 \mathrm{MPa}$. An increase in temperature resulted in lower enantioselectivity, whereas changes in pressure and density had a slight effect. Using a fixed amount of enzyme, concentrations of lavandulol from 10 to $120 \mathrm{mM}$ were tested in the reactor, keeping constant the stoichiometric ratio of $1: 1$. The highest conversion after $4 \mathrm{~h}$ of reaction was of $44 \%$ using $60 \mathrm{mM}$ of substrates. The conversion was determined in several periods of time above $24 \mathrm{~h}$ of reaction at temperatures from 25 to $80{ }^{\circ} \mathrm{C}$ and pressures of 10 and $15 \mathrm{MPa}$. An additional experiment was carried out in the critical point of the 
Table 1 Matrix of the first $2^{3}$ experimental design (coded and real values) with the responses expressed as reaction conversion to geranyl oleate

\begin{tabular}{lcclc}
\hline Run & Temperature $\left({ }^{\circ} \mathrm{C}\right)$ & $\begin{array}{l}\text { Geraniol/acid } \\
\text { molar ratio }\end{array}$ & $\begin{array}{l}\text { Enzyme } \\
\text { concentration (wt\%) }\end{array}$ & Conversion (\%) \\
\hline 1 & $-1(40)$ & $-1(1: 1)$ & $-1(1)$ & 81.83 \\
2 & $1(60)$ & $-1(1: 1)$ & $-1(1)$ & 86.47 \\
3 & $-1(40)$ & $1(5: 1)$ & $-1(1)$ & 93.12 \\
4 & $1(60)$ & $1(5: 1)$ & $-1(1)$ & 98.05 \\
5 & $-1(40)$ & $-1(1: 1)$ & $1(10)$ & 93.53 \\
6 & $1(60)$ & $-1(1: 1)$ & $1(10)$ & 94.35 \\
7 & $-1(40)$ & $1(5: 1)$ & $1(10)$ & 98.50 \\
8 & $1(60)$ & $1(5: 1)$ & $1(10)$ & 69.36 \\
9 & $0(50)$ & $0(3: 1)$ & $0(5.5)$ & 97.27 \\
10 & $0(50)$ & $0(3: 1)$ & $0(5.5)$ & 97.27 \\
11 & $0(50)$ & $0(3: 1)$ & $0(5.5)$ & 98.71 \\
\hline
\end{tabular}

Table 2 Matrix of the second experimental design (coded and real values) with responses in terms of reaction conversion to geranyl oleate, at $40{ }^{\circ} \mathrm{C}, 150 \mathrm{rpm}$ and $6 \mathrm{~h}$

\begin{tabular}{lcll}
\hline Run & $\begin{array}{l}\text { Geraniol/acid } \\
\text { molar ratio }\end{array}$ & $\begin{array}{l}\text { Enzyme } \\
\text { concentration } \\
\text { (wt\%) }\end{array}$ & $\begin{array}{l}\text { Conversion } \\
(\%)\end{array}$ \\
\hline 1 & $-1(1: 1)$ & $-1(1)$ & 80.09 \\
2 & $1(5: 1)$ & $-1(1)$ & 85.74 \\
3 & $-1(1: 1)$ & $1(10)$ & 92.03 \\
4 & $1(5: 1)$ & $1(10)$ & 94.12 \\
5 & $0(3: 1)$ & $0(5.5)$ & 91.68 \\
6 & $0(3: 1)$ & $0(5.5)$ & 92.22 \\
7 & $0(3: 1)$ & $0(5.5)$ & 90.29 \\
\hline
\end{tabular}

carbon dioxide, at $31{ }^{\circ} \mathrm{C}$ and $7.4 \mathrm{MPa}$. Results showed that Novozym 435 was able to promote acetylation from lavandulol in supercritical carbon dioxide at temperatures up to $80^{\circ} \mathrm{C}$, presenting a maximum conversion at $10 \mathrm{MPa}$ and $60{ }^{\circ} \mathrm{C}$ after $24 \mathrm{~h}$ of reaction. An enhancement in reaction rate was also observed when $n$-hexane was used as solvent.

Castro et al. [12] studied the synthesis of terpenoid esters by enzymatic route and the influence of the chain length of the fatty acid and the structure of terpenic acid was evaluated. The study was carried out using fatty acids from 2 to 18 atoms of carbon and esterification rates of 95 and $98 \%$ were reached for acids with four or more carbon atoms. In a second set of experiments, different terpenic alcohols were esterified using butyric acid. The structure of the alcohol showed high influence on reaction rate. Esterification grades higher than $95 \%$ were obtained for primary alcohols as citronellol, geraniol and nerol. Secondary (menthol) and tertiary (linalool) alcohols were not esterified in the tested experimental conditions.

The experimental conditions tested by Castro et al. [12] for the esterification of primary, secondary and tertiary

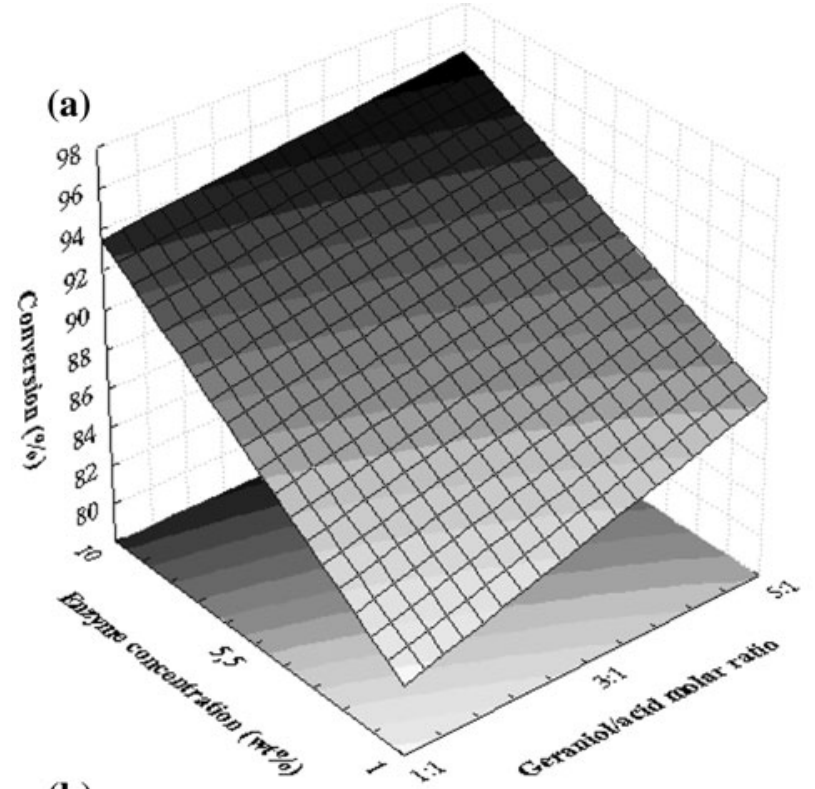

(b)

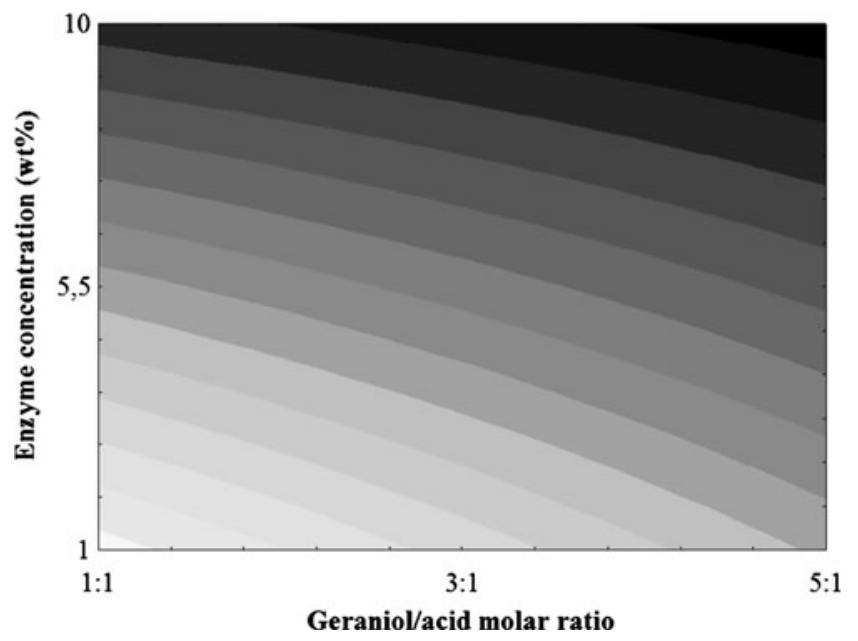

Fig. 1 Response surface (a) and contour curve (b) for the production of geranyl oleate as a function of enzyme concentration and substrates molar ratio 
alcohols using Lipozyme IM as catalyst (10 wt \% in relation to the total mass of substrates) in batch mode $\left(45^{\circ} \mathrm{C} /\right.$ $24 \mathrm{~h} / 150 \mathrm{rpm}$ ) using $n$-heptane as solvent showed that the tertiary alcohols were not esterified. The authors also tested the production of esters from primary alcohols in solventfree system. Results obtained by Castro et al. [12] are comparable to those obtained here, showing the positive effect of enzyme concentration and substrates molar ratio on geranyl oleate production. Here, high conversions (about 94\%) were obtained after $6 \mathrm{~h}$ of reaction, at $40{ }^{\circ} \mathrm{C}$ in solvent-free system.

Kinetic evaluation of enzymatic production of geranyl oleate

The effects of substrates molar ratio, temperature and enzyme concentration were investigated on the kinetics of geranyl oleate production. As presented earlier, the execution of two experimental designs with the abovementioned variables revealed the achievement of high conversions in $6 \mathrm{~h}$ of reaction at $40{ }^{\circ} \mathrm{C}, 150 \mathrm{rpm}$, substrates molar ratio of $3: 1$ and $10 \mathrm{wt} \%$ of enzyme. It may be important to mention that the kinetic results subsequently presented in this work are in fact mean values of triplicate runs, which resulted in an overall absolute deviation in terms of reaction conversion of around 5\%. Data scattering observed in kinetic esterification data may be explained in terms of experimental errors associated, and the fact that destructive experiments were carried out without sampling, which may be viewed as an important internal consistence test of the results. Thus, the well behavior verified for the conversion versus time curves may assure the reliability of the experimental measurements reported in the present work.

\section{Effect of geraniol to oleic acid molar ratio}

The experiments for evaluating the effect of geraniol to oleic acid molar ratio on the reaction kinetics were carried out keeping constant the temperature $\left(50{ }^{\circ} \mathrm{C}\right)$, enzyme concentration (5.5 wt \% based on substrates) and $150 \mathrm{rpm}$. Figure 2 presents the experimental curves obtained for substrates molar ratio of 1:1, 3:1 and 5:1.

From this figure, one can observe that after $30 \mathrm{~min}$ of reaction, similar initial rates $\left(1.66,1.55\right.$ and $\left.1.61 \mathrm{~min}^{-1}\right)$ were obtained for three tested molar ratios, demonstrating that, in the range evaluated, this variable does not present significant difference. After $1 \mathrm{~h}$ of reaction, similar conversions were achieved, higher than $90 \%$.

The substrates molar ratio is usually one of the most important parameters in enzymatic esterification reactions. Since the reaction is reversible, a raise in the concentration of one substrate can displace the chemical equilibrium to product formation, hence resulting in higher conversions. On the other hand, high substrate concentrations may reduce the reaction rate due to the inhibition effect [14-17]. He et al. [3] evaluated the effect of acid to alcohol molar ratio on the enzymatic synthesis of 2-ethylhexyl palmitate in petroleum ether system at 4:1, 3:1, 2:1, 1:1, 1:2, 1:3 and $1: 4$, at $40{ }^{\circ} \mathrm{C}$, using an immobilized lipase from Candida sp. 99-125 (10 wt \% based on the amount of substrates). The authors observed higher conversion $(86 \%)$ at molar ratios of $4: 1$ and $2: 1$.

Another way to shift the equilibrium of a specific reaction is removing the by-product formed. The water produced during the esterification reaction can be considered the most important parameter to be controlled. Under conditions of low water concentration, $1 \mathrm{~mol}$ of water is produced for each mol of ester. The removal of water by several methodologies can prevent this phenomenon and consequently conduct to high conversions [18]. The use of molecular sieves along the present work can explain the high conversion (93.7\%) achieved for the molar ratio of 1:1 after $1 \mathrm{~h}$ of reaction (Fig. 2).

\section{Effect of enzyme concentration}

The effect of enzyme concentration (1, 2, 5.5 and $10 \mathrm{wt} \%)$ on the reaction kinetics was evaluated keeping fixed the temperature $\left(50{ }^{\circ} \mathrm{C}\right)$, geraniol to oleic acid molar ratio $(3: 1)$ and $150 \mathrm{rpm}$, making possible to build the kinetic curves as a function of reaction time (Fig. 3). From this figure, one can verify the significant influence of enzyme concentration on geranyl oleate production. Using $10 \mathrm{wt} \%$ of enzyme, high initial rate $\left(3.30 \mathrm{~min}^{-1}\right)$ was obtained, reflecting high conversions (98.9\%) after $30 \mathrm{~min}$ of reaction. As can also be observed from Fig. 3, there is a tendency of conversion to reach equilibrium after $3 \mathrm{~h}$ of

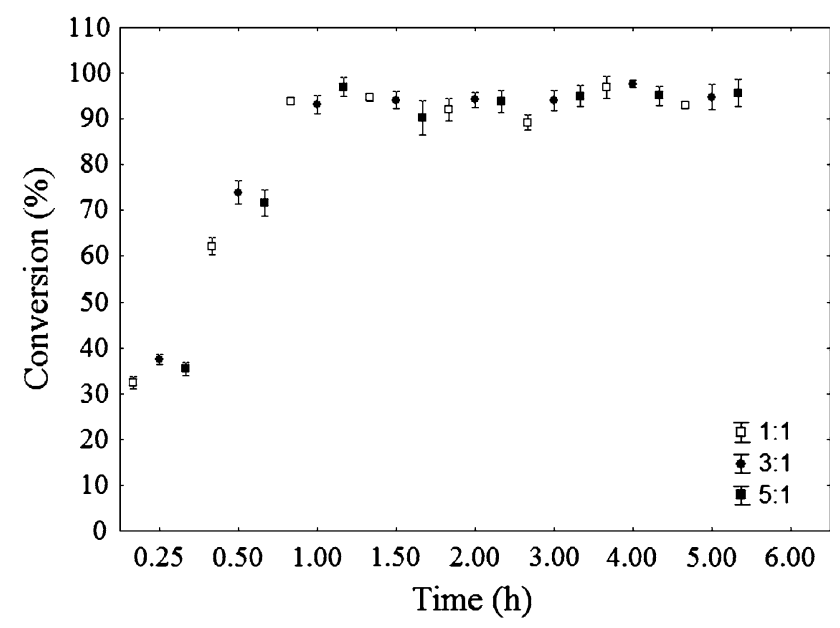

Fig. 2 Effect of substrates molar ratio on the production of geranyl oleate at $50{ }^{\circ} \mathrm{C}$, enzyme concentration of $5.5 \mathrm{wt} \%$ and $150 \mathrm{rpm}$ 


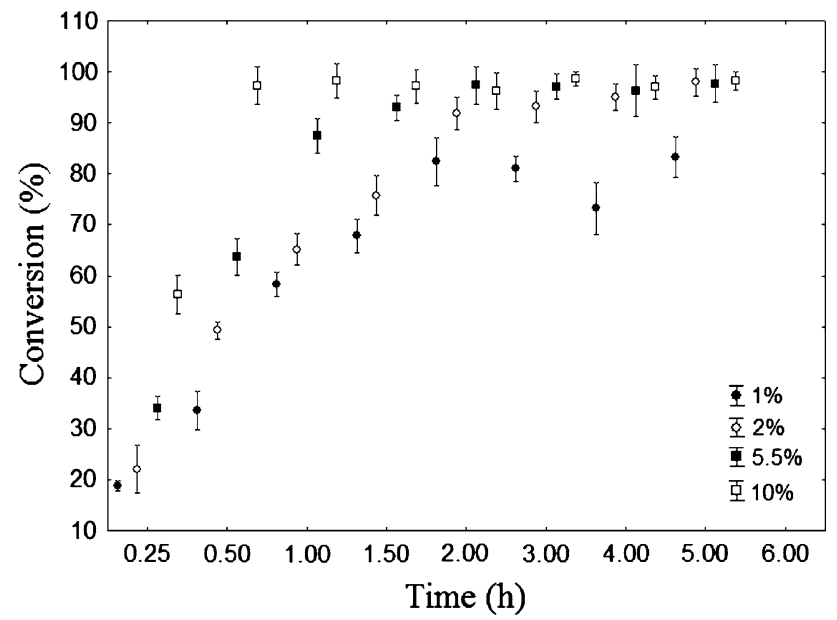

Fig. 3 Effect of enzyme concentration on the production of geranyl oleate at $50{ }^{\circ} \mathrm{C}$, geraniol to oleic acid molar ratio of 3:1 and $150 \mathrm{rpm}$

reaction when enzyme concentrations from 2 to $10 \mathrm{wt} \%$ were used.

A possible explanation might be related to the fact that an excess of enzyme in the reactional medium could not contribute to the conversion enhancement, since high enzyme concentration may lead to the formation of aggregates, thus not making the enzyme active site available to the substrates [19-21]. The enzyme molecules on external surface of such particles are exposed to high substrate concentrations, but the mass transport could drastically limit the substrate concentration inside the particles. Lower activities of the biocatalyst reduce the efficiency of the enzyme, not enhancing the reaction conversion [22].

\section{Effect of temperature}

To evaluate the effect of temperature $\left(40,50\right.$ and $\left.60{ }^{\circ} \mathrm{C}\right)$ on geranyl oleate conversion, geraniol to oleic acid molar ratio (3:1), enzyme concentration (5.5 wt $\%$ ) and agitation (150 rpm) were kept constant. The kinetic curves obtained in this step are presented in Fig. 4. Similar initial rates $\left(2.28,2.39\right.$ and $\left.2.81 \mathrm{~min}^{-1}\right)$ were obtained for 40,50 and $60{ }^{\circ} \mathrm{C}$, respectively.

Temperature usually presents two important roles in this kind of reactional system. Firstly, an increase in temperature can reduce mixture viscosity, enhance mutual solubility and improve diffusion process of substrates, thus reducing mass transfer limitations and favoring interactions between enzyme particles and substrates. Besides, enzymes generally have an optimal working temperature value, and in the case of Novozym 435 , it is situated in the range of $40-70{ }^{\circ} \mathrm{C}$ [23].

Güvenç et al. [24] studied the esterification of isoamyl acetate catalyzed by Novozym 435 and Lipozyme RM IM

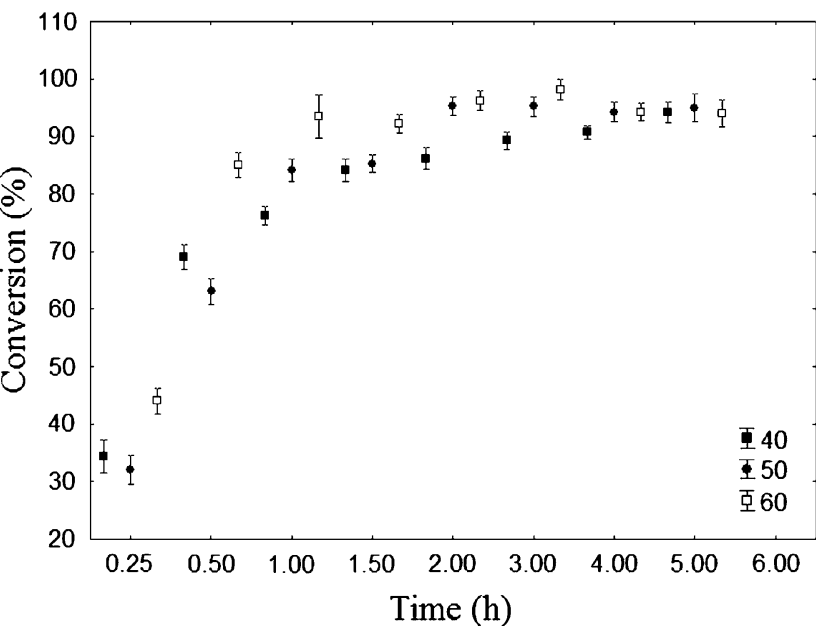

Fig. 4 Effect of temperature on the production of geranyl oleate at geraniol to oleic acid molar ratio of 3:1, enzyme concentration of $5.5 \mathrm{wt} \%$ and $150 \mathrm{rpm}$

in solvent-free system. Acid to alcohol molar ratio of 1:2 using Novozym 435 led to the reaction equilibrium after $6 \mathrm{~h}$ at 30,40 and $50{ }^{\circ} \mathrm{C}$ with conversions of about $81 \%$. The use of Lipozyme RM IM and acid to alcohol molar ratio of $1: 1$, after $48 \mathrm{~h}$ of reaction, conducted to conversions of $20 \%$ at $50{ }^{\circ} \mathrm{C}$ and $13 \%$ at $30{ }^{\circ} \mathrm{C}$.

From Fig. 4, one can verify that at $60{ }^{\circ} \mathrm{C}$ after $1 \mathrm{~h}$ of reaction a conversion in geranyl oleate of about $93 \%$ was achieved. It is also possible to note that the reaction conversion enhances as a function of time and reaches a maximum conversion of $95 \%$ in $2 \mathrm{~h}$ of reaction for temperatures of 50 and $60{ }^{\circ} \mathrm{C}$. He et al. [3] used a lipase from Candida sp. 99-125 in a petroleum ether system and studied the effect of temperature on 2-ethylhexyl palmitate production. The authors observed that when temperature was controlled in the range from 40 to $50{ }^{\circ} \mathrm{C}$, the product yield increased. Conversely, when temperature was enhanced from 50 to $70{ }^{\circ} \mathrm{C}$, the reaction yield decreased.

Finally, it may be relevant to mention that measurements of enzyme activity before (fresh) and after (used) reaction experiments revealed no important changes in residual lipase activity, thus suggesting possible enzyme reuse. In this sense, the enzyme was tested for ten consecutive cycles, at the optimized experimental condition established in the experimental design. After this procedure, the residual activity (data not shown), defined as the ratio of final activity/initial activity $\times 100$, was about $95 \%$ (initial activity of around $60 \mathrm{U} / \mathrm{g}$ ), hence a warranty that the biocatalyst can be used for successive batches without important loss of activity.

In attempt to better understand the esterification reaction in solvent-free system, further experiments using other commercial and non-commercial enzymes are underway within our working group. 


\section{Conclusions}

New experimental data on enzymatic esterification of geraniol and oleic acid for geranyl oleate production are reported in this work, showing a promising perspective of the technique to overcome the well-known drawbacks of the chemical-catalyzed route. Results of the reactions showed that the strategy adopted for the experimental design proved to be useful in evaluating the effects of the studied variables on the reaction conversion using Novozym 435 as catalyst. The operating conditions that maximized geranyl oleate production were determined to be geraniol to oleic acid molar ratio of $3: 1,40{ }^{\circ} \mathrm{C}, 150 \mathrm{rpm}$ and $10 \mathrm{wt} \%$ of enzyme, leading to a reaction conversion of about $93 \%$. From the kinetic study, one could verify that an excess of alcohol (acid to alcohol molar ratio of 1:6), relatively low enzyme concentration ( $5 \mathrm{wt} \%$ ), temperature of $40{ }^{\circ} \mathrm{C}$ and molar ratio of $1: 1$ led to nearly complete conversion after $1 \mathrm{~h}$ of reaction.

Acknowledgments The authors thank CNPq, CAPES and URICampus de Erechim for the financial support and scholarships.

\section{References}

1. Malcata FX, Reyes HR, Garcia HS et al (1990) JAOCS 67:890

2. http://www.leffingwell.com/top_10.htm. Accessed 29 June 2010

3. He X-L, Chen B-Q, Tan T-W (2002) J Mol Catal B Enzyme 18:333

4. Tan T, Chen B-Q, Ye H (2006) Biochem Eng J 29:41
5. Treichel H, Oliveira D, Mazutti MA et al (2010) Food Bioprocess Technol 3:182

6. Koblitz MGB (2003) Purificação e caracterização de lipase de Rhyzopus sp. e sua aplicação na síntese de monoacilgliceróis. $\mathrm{PhD}$ thesis. UNICAMP, Campinas (in Portuguese)

7. Dalla-Vechia R, Nascimento MG, Soldi V (2004) Quim Nova 27:623

8. Oliveira D, Feihrmann AC, Rubira AF et al (2006) J Supercrit Fluids 38:373

9. Paroul N, Grzegozeski LP, Chiaradia V et al (2010) J Chem Technol Biotechnol. doi:10.1002/jctb.2475

10. Castro HF, Mendes AA, Santos JC (2004) Quim Nova 27:146

11. Chaar J (2000) Estudos analíticos e modificação química por acetilação do linalool contido no óleo essencial de espécie Aniba duckei Kostermans. Tese de doutorado. Instituto de Química de São Carlos, da Universidade de São Paulo, São Carlos, SP

12. Castro HF, Oliveira PC, Soares CAF (1997) Ciência e Tecnologia de Alimentos 17:197

13. Olsen T, Kerton F, Marriott R et al (2006) Enzyme Microb Technol 39(4):621-625

14. Burham H, Rasheed RAGA, Noor NM et al (2009) J Mol Catal B Enzyme 58:153

15. Chang SW, Yang CJ, Chen FY et al (2009) J Mol Catal B Enzyme 56:7

16. Lv L-X, Pan Y, Li Y-Q (2007) Food Chem 101:1626

17. Hsieh H, Nair GR, Wu W (2006) J Agric Food Chem 54:5777

18. Irimescu R, Saito T, Kato K (2004) J Mol Catal B Enzyme 27:69

19. Watanabe T, Shimizu M, Sugiura M et al (2003) JAOCS 80:1201

20. Yang T, Rebsdorf M, Engelrud U et al (2005) J Agric Food Chem 53:1475

21. Valério A, Fiametti KG, Rovani S et al (2009) J Supercrit Fluids 49:216

22. Karra-Châabouni M, Ghamghi H, Bezzine S et al (2006) Process Biochem 41:1692

23. Kristensen JB, Xu X, Mu H (2005) J Agric Food Chem 53:7059

24. Güvenç A, Kapucu N, Mehmetoglu Ü (2002) Process Biochem $38: 379$ 